脳乏虚血時の脳組織エネルギー代謝に及ぼす S-adenosyl-Lmethionine の効果に関する研究

$\begin{array}{lrrr}\text { 関本 } & \text { 博 } & \text { 中西 } & \text { 正人 松谷 芳英 } \\ \text { 島田 } & \text { 修史 } & \text { 中野 } & \text { 利美 }\end{array}$

要旨：S-adenosyl-L-methionine（SAM）の脳組織内エネルギー代謝に及ぼす効果を明らか にすることを目的に，マウスを用い脳虚血モデルについて経時的に解糖系を中心に検討を加兄 た. 断頭後の脳内 phosphocreatine, ATP, glucose, glycogen および lactateの変化を検討した ところ, 対照群では脳組織内在性エネルギー源のすみやかな減少と lactate の増加が認められ た. SAM 投与群では断頭時すでに脳内 glucose の有意な増加が認められ，断頭後，脳組織内在 性エネルギー源濃度は対照群に比して高い值を示した。断頭後の high energy phosphate utilization を検討したところ，断頭10秒後まではSAM 投与群では対照群の77.1\%に抑制されてお り，断頭による脳組織内在性エネルギー源の枯渴までの時間が SAM 投与により延長された。以 上の結果から SAM がマウスの脳虚血に対して保護作用を有することが明らかとなり，臨床的 に脳血管障害時の脳虚血に対して有効である可能性が示唆された。

Key words : S-adenosyl-L-methionine, cerebral ischemia, cerebral energy metabolism

(脳卒中 $6: 405-410,1984$ )

\section{緒言}

S-adenosyl-L-methionine (SAM)は, Fig. 1に示す 構造を有し，1951年 Cantoni らによって生体内に抢け るメチル基転移反応のメチル基供与体として発見同定 され12), 今日末でにその生理的機能も徐々に解明され てきた。臨床的には1973年に Fazioらが抑らつ症状の 治療に有効であることを報告到し，現在諸外国に扔い て抗抑うつ薬として使用されている。また，我々はす でに, 実験的脳出血に扮いて脳血管の微細構造の破綻 とともに脳組織のエネルギー代謝の虚血性変化，すな わち脳組織内 phosphocreatine, ATP, glucose, glycogen の減少拈よび lactateの増加が惹起される ことを報告した ${ }^{4) 5}$. 脳内カテコールアミン代謝に関す るSAM の研究 ${ }^{6 / 7)}$ は数多いが, 脳組織のエネルギー代 謝に対するSAM の作用を検討した報告は無い。今回 我々は, SAM の新しい臨床効果を検討すべく, SAM の脳組織内土ネルギー代謝の基礎的治験に及ぼす効果 を明らかにすることを目的として，マウスを用い断頭 による脳虚血モデルについて経時的に解糖系を中心に

金沢医科大学老年病学教室

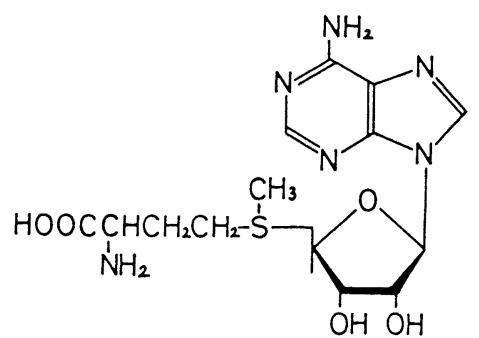

Fig. 1 S-adenosyl-L-methionine (SAM)

検討を加えたので報告する。

\section{方法}

\section{1) 実験動物および薬物投与法}

体重25２8g の雄性 dd マウスを 1 群 6 匹として使 用した. SAM は0.36 $\mathrm{M} \mathrm{Na}_{2} \mathrm{H} \mathrm{PO}_{4}$ に溶解し, $\mathrm{pH}$ を6.0 とした後, 生理食塩水にて投与容量が体重 $10 \mathrm{~g}$ あたり $0.1 \mathrm{~m} l$ となるように濃度を調製した。対照群には生理 食塩水を，薬物投与群には SAM $100 \mathrm{mg} / \mathrm{kg}$ をマウス の尾静脈内に投与し，30分後にマウスを断頭した。断 頭10秒および30秒後に頭部を液体窒素中ですばやく凍 結した。な扔，断頭 0 秒として，生理食塩水㧤よび薬 物投与 30 分後のマウスの頭部を, 断頭せずに液体窒素 
中で涷結した。

2）脳組織内代謝物の試料調製法と測定法

冷凍室内で脳をドライアイス上で涷結状態のまま摘

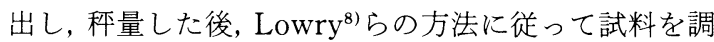
製した。すなわち，脳を液体窒素内で冷凍のまま木モ ブレンダーで粉末にし, 予め $1 \mathrm{~m} l$ の $3 \mathrm{M} \mathrm{HClO}_{4}$ を入れ 凍結した試験管にこの粉末を移し, $-10^{\circ} \mathrm{C} て ゙ \mathrm{HClO}_{4}$ と 混和し，これに $3 \mathrm{~m} l$ の $3 \mathrm{mM}$ EDTA を加え homogenize したのち, $18,000 \mathrm{~g}, 15$ 分間遠心分離した. 分取した 上清 $3.5 \mathrm{~m} l に 1.5 \mathrm{~m} l$ の $2 \mathrm{M} \mathrm{KHCO}_{3}$ を加光中和し, 遠心 分離 $(18,000 \mathrm{~g}, 15 \mathrm{~min})$ 後上清を用いて, phosphocreatine, ATP および glucose は酵素法により生成す る NADPH を蛍光測定(励起波長 $350 \mathrm{~nm}$, 蛍光波長 460 $\mathrm{nm}$ ）した ${ }^{819)}$. lactateは，酵素法により生成する NADH を比色測定 (340nm) した (Technical Bulletin No. 826-UV. Sigma Chemical, Co). glycogen homogenate の $18,000 \mathrm{~g}$ 遠心分離により得た沈渣を Good らの方法 ${ }^{101}$ に準じ，アルコール沈殿により分離 乙, 酸加水分解後, glucose-oxidase 法 (Blood Sugar Test TC-M-II, Boehringer Mannheim Corp.）を用い 比色定量した。結果は脳 $1 \mathrm{~g}$ あたりの $\mu \mathrm{mol}$ として表示 した。

3）脳組織の high energy phosphate utilization の算出

断頭後の脳組織内在性エネルギー源濃度の変化量か
ら Lowryらの式8゙とり high energy phosphate utilization を算出した。

High energy phosphate utilization $(\mu \mathrm{mol} / \mathrm{g} /$ $\min )=\Delta \mathrm{Phosphocreatine}+2 \Delta \mathrm{ATP}+2$ $\Delta$ Glucose $+2.9 \Delta$ Glycogen

結果は, 1 分間の脳 $1 \mathrm{~g}$ あたりの $\mu \mathrm{mol}$ 変化量として 表示した。

\section{4）血中 glucose および lactate の測定法}

断頭によって採取した血液 $0.2 \mathrm{~m} l$ を $2.0 \mathrm{~m} l$ の 0.33 $\mathrm{M} \mathrm{HClO}_{4}$ に加兄擋挥し，遠心分離 $(18,000 \mathrm{~g}, 15 \mathrm{~min})$ により除蛋白後, 上清について glucose 抢よび lactate をそれぞれ比色法によって測定した。結果は, 血液 $1 \mathrm{~m} l$ 中の $\mu \mathrm{mol}$ として表示した。

\section{結果}

断頭後の脳組織内在性エネルギー源濃度変化に及注 すSAM の影響をFig. 2に示した。対照群では，内在 性エネルギー源のうち phosphocreatine の断頭後の 減少が最も著明であり，10秒後には $44 \%$ に，30秒後に は19\%に減少した。 phosphocreatine に次いで glucose, ATP, glycogen の順に減少し, glycogen 断頭 10 秒後では $89 \% ， 30$ 秒後でも $71 \%$ 残存しており最 も遅い速度で減少した。これらの内在性エネルギー源 の減少に伴い, lactateの有意な増加が認められ, 断頭 10秒後では $174 \% ， 30$ 秒後には235\%に増加した。断頭

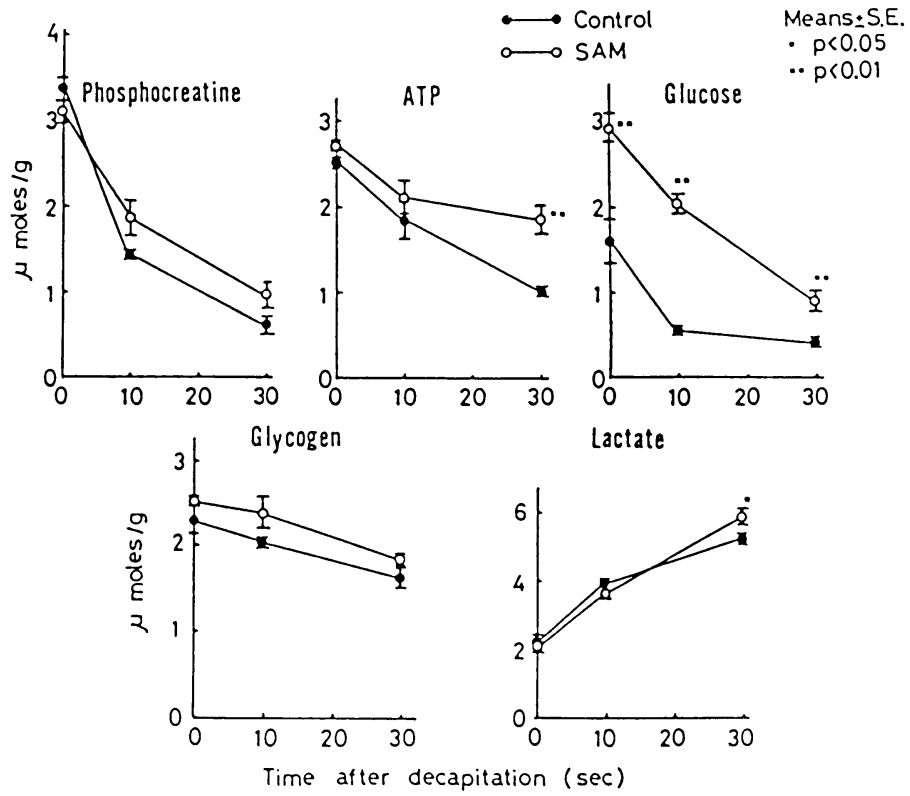

Fig. 2 断頭後の脳組織内在性エネルギー源濃度变化に及注すSAMの影響 
時の脳組織内在性エネルギー源濃度に及ぼすSAMの 影響を検討した場合, phosphocreatine, ATP, glycogen 技よび lactate には有意な変化は認められ なかったが, glucose では対照群の $1.61 \mu \mathrm{moles} / \mathrm{g}$ に対 し SAM 投与群では $2.93 \mu$ moles $/ g$ となり有意な増加 が認められた。次に断頭後の内在性エネルギー源濃度 を検討すると，断頭10秒ならびに30秒後のいずれにお いても, SAM投与群で対照群に比し, phosphocreatine, ATP, glucose 㧍よび glycogen 濃度に高值 が認められた. lactateについては, 断頭10秒後では対 照群に比して SAM 投与群が低值を示したが，30秒後 には逆に高值を示した。これらの内在性エネルギー源 濃度の断頭10秒後までの変化量を table 1に示した。 phosphocreatine は対照群の $10.97 \mu \mathrm{moles} / \mathrm{g} / \mathrm{min} に$ 対して SAM 投与群では $7.60 \mu \mathrm{moles} / \mathrm{g} / \mathrm{min}$ となり, その減少が $69.3 \%$ に抑制された。また, ATP は $92.6 \%$, glucose は $84.7 \%$, glycogen $45.4 \%$ にそれぞれの減 少が抑制された. lactate はSAM の投与によってその 増加が対照群の $94.3 \%$ となり, やや抑制される傾向を 示した。したがって, これらの内在性エネルギー源濃 度の変化量から high energy phosphate utilization を 算出すると, 対照群の $36.2 \mu \mathrm{moles} / \mathrm{g} / \mathrm{min}$ に対して $\mathrm{SAM}$ 投与群では $27.9 \mu \mathrm{moles} / \mathrm{g} / \mathrm{min}$ となり, 断頭 10 秒後までの脳組織の high energyphosphate utilizationはSAM 投与によって $77.1 \%$ に低下していた。同 様に断頭 10 秒後から 30 秒後までの high energy phosphate utilizationを算出すると, 対照群では 12.0 $\mu \mathrm{moles} / \mathrm{g} / \mathrm{min}, \mathrm{SAM}$ 投与群では $15.7 \mu \mathrm{moles} / \mathrm{g} / \mathrm{min}$ であった(Fig. 3). 血液中 glucose 㧍よび lactate 濃度 に及ぼすSAM の影響をFig. 4 亿示した. SAM の投 与によって, 血液中 glucose は有意に増加した。一方, lactate には有意な変化は認められなかった。

Table 1 断頭時から断頭10秒後までにおける脳組織 内在性エネルギー源濃度の変化速度

\begin{tabular}{|c|c|c|}
\hline & Control & SAM \\
\hline & \multicolumn{2}{|c|}{ umoles $/ \mathrm{g} / \mathrm{min}$} \\
\hline$\Delta$ Phosphocreatine & 10.97 & $7.60(69.3 \%)$ \\
\hline$\triangle \mathrm{ATP}$ & 4.06 & $3.76(92.6 \%)$ \\
\hline$\Delta$ Glucose & 6.35 & $5.38(84.7 \%)$ \\
\hline$\Delta$ Glycogen & 1.52 & $0.69(45.4 \%)$ \\
\hline$\Delta$ Lactate & 9.98 & $9.41(94.3 \%)$ \\
\hline $\begin{array}{l}\text { High Energy Phosphate } \\
\text { Utilization }\end{array}$ & 36.2 & $27.9 \quad(77.1 \%)$ \\
\hline
\end{tabular}

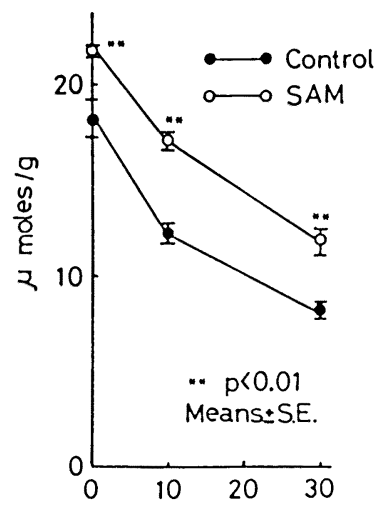

Time after decapitation ( $\mathrm{sec}$ )

Fig. 3 断頭後の脳組織内 High Energy Phosphate 濃度変化に及ぼす SAM の影響

High Energy Phosphate $=$ Phosphocreatine +2 ATP + 2Glucose +2.9Glycogen

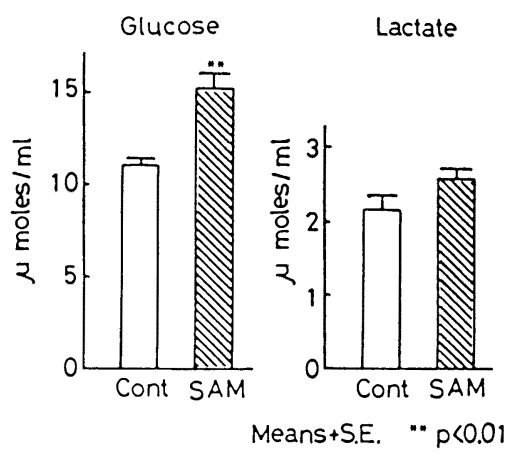

Fig. 4 断頭時の血中 Glucose おょび Lactate 濃度 に及ぼす SAM の影響

\section{考察}

マウスの断頭虚血により, 脳組織内在性エネルギー 源である phosphocreatine, ATP, glucose 扰よび glycogenのすみやかな減少と lactateの増加が認め られた。実験的脳出血や実験的脳梗塞に打いても同様 に脳組織内在性エネルギー源の減少と lactateの増加 がみられるが5)11) 15), いずれの場合でも phosphocreatine が最もはやく減少し, 次いでATP, glucose, glycogen が減少し, また, lactate は phosphocreatine の減少に続いてはやく増加するとされている。すなわ ち, このような脳虚血時には, 脳組織への酸素とエネ ルギー源の供給が停止され，まず過剰の ATP の貯蔵 物質である phosphocreatine が減少する。次に glucose および glycogen は嫌気的に解糖され，Emb- 
den-Meyerhof 経路によって pyruvateを経て lactate へと分解され, 脳組織内に lactate の蓄積が㧍こる。こ の結果 lactate 蓄積によるアシドーシスと脳組織内在 性エネルギー源の絶対的な不足により, 脳機能は低下 しさらには停止すると考劣られる. SAM は active methionine と呼ばれ, 生体内では methionine と ATP の縮合反応により生成され, SAM の有する S- メ チル基が生体内の種々のメチル基転移反応に使用され る. SAM が関与する生体内反応の主なものは, methionine から SAM を経て cysteine, glutathione を生成 寸る生体内硫化物代謝，カテコールアミン代謝系に招 ける norepinephrine から epinephrine への変換とカ テコールーOーメチルトランスフェラーゼ (COMT) が関与するメチル基転移反応, 生体内主要リン脂質で ある phosphatidyl choline の生成反応，拈よびポリア ミン合成系に打ける putrescineから spermidine, spermine の生成 ${ }^{16)}$ 等がある. マウスの断頭虚血実験に おいて, 断頭時の脳組織内エネルギー源濃度に及注す SAM の影響を検討した場合, 脳内 glucose が対照群 に比してSAM 投与群で有意に増加して抢り, これが 脳組織内 high energy phosphate の有意な増加の主因 をなしていると考兄られた。この時血中 glucose も同 様に SAM 投与群で有意に上昇して抢り，このことが 脳組織内 glucose 濃度の上昇に一部関与していると考 えられる。SAM は生体内カテコールアミン生合成系 に打ける dopa $\rightarrow$ dopamine $\rightarrow$ norepinephrine $\rightarrow$ epinephrine の過程でフェニルェタノールアミンーN 一メチルトランスフェラーゼにより行なわれる norepinephrine から epinephrine への変換にメチル基供与 体として関与して㧍り，カテュールアミン代謝系にお いてもCOMTにより行なわれる dopamine, norepinephrine, epinephrine の分解反応に関与している. Stramentinoli'b)らは，ラットに $\mathrm{H}^{3}$-tyrosine を脳室内 投与して大脳皮質に怙ける norepinephrine への変換 率を求めたところ, SAM 投与群で対照群の約 2 倍で あり，をた norepinephrine の主代謝物である3-methoxy-4-hydroxy phenylglycol 測定すると SAM 投 与群では対照群に比して有意に増加しており, SAM は norepinephrine の代謝回転を増大させると報告し ている。また, SAM は現在諸外国において抑らつ病治 療薬として使用されて抢り, これはカテュールアミン の絶対的, 相対的不足が原因の 1 つとされる抑らつ病 に SAM のカテコールアミンの増加作用が有効である ためとされている7゙.マウスに拈いて SAM 投与によ
り血中 glucose が上昇したことは，カテコールアミン の代謝回転の増大に起因すると考光られる。SAMは また, phosphatidyl choline の生成にも関与している。 phosphatidyl choline の生成には 4 つの系があり，そ のうち CDP-choline が補酵素として働く Kennedy PathwayとSAMによる phosphatidyl ethanolamine のメチル化 (Greenberg pathway) の 2 つが主流とさ れて抢り，そして後者によるものが前者の50倍である とされている17). phosphatidyl choline は細胞膜りン 脂質の主要な構成成分であり, SAM 投与によって人 赤血球膜の流動性が増大したという報告 ${ }^{18) や ， ま た ， ~}$ 我々もリン脂質のある種のものが実験的脳出血におい て脳動脈内皮細胞の保護作用を示すことを報告5)199 て抢り, SAM 投与による脳組織内 glucose 濃度の上 昇は, 脳組織細胞膜に対する何らかの機序により, glucoseの組織内含量が増加したためとも考学られ る. 次に断頭後の脳組織内在性エネルギー源濃度の変 化について考察を加える. 断頭10秒後までの内在性工 ネルギー源の変化量は phosphocreatine, ATP, glucose, glycogen ともにSAM 投与群で対照群に比 して小さくなって抢り, high energy phosphate utilization は対照群の77.1\%に低下していた。特に phosphocreatine の変化量は69.3\%に低下しており, 脳虚 血時, 最初に消費される phosphocreatine の消費の低 下は, SAM 投与によって脳組織内のエネルギー消費 の抑制を示唆すると考兄られる。断磌10秒後までの high energy phosphate utilizationについては, 酸素 消費量から算出した断頭前の high energy phosphate utilization と核汸一致するという報告8)11201 22)があ り, 断頭10秒後までの脳組織内ェネルギー代謝の様相 から, 断頭直前の脳組織内エネルギー代謝を知ること が可能であると考えられている.

今回の実験で, SAM 投与による断頭10秒後までの high energy phosphate utilization の低下は, SAM の 脳組織内エネルギー消費の抑制作用を示唆するものと 考えられる. glucose の投与によって脳組織内 glucose 濃度を上昇させ, 脳組織内在性エネルギー源濃度を上 昇させた報告 ${ }^{23)}$ もあが, 追跡時間単位がいちじるし く延びて抢り, 我々の成績と同じレベルで論ずること はできないが，SAM 投与時に認められたような断頭 10秒後の high energy phosphate utilization の低下は 認められていない。これらの成織から, SAMの作用 は, 単に血中おょび脳組織中 glucose の上昇のみで理 解することはできず, 何らかの機序による high 
energy phosphate utilization 抑制の存在が考学られ る. 断頭 10 秒後から 30 秒後までの内在性エネルギー源 の変化量は, 結果の項に述べたごとく, 対照群では glucose がほぼ枯渴状態となりエネルギー源として利 用できなくなっていた。断頭10秒後から 30 秒後までの high energy phosphate utilizationは断頭10秒後まで の $33.1 \%$ に低下し, 絶対的なエネルギ一源の不足状態 となっているものと考党られる。一方, SAM 投与群で は, high energy phosphate utilization は断頭10秒後 までの $56.3 \% て ゙ あ り ，$ 対照群ほどのエネルギー源の不 足状態には至っていないと考兄られる。 マウスの断頭 虚血実験に唡いて, SAM 投与により脳組織内在性土 ネルギー源濃度が上昇し, 断頭後の high energy phosphate utilizationの抑制作用も加わり, 断頭後の脳組 織内在性エネルギー源の絶対的な不足状態までの時間 が延長される成績を得た。これは, SAM が脳虚血に対 して保護作用を有することを示すものであり，臨床的 にも脳血管障害急性期における脳虚血に対して有効で ある可能性が示唆された。

\section{結語}

SAM の脳組織内エネルギー代謝に及ぼす効果を明 らかにすることを目的に，マウスを用い脳虚血モデル について経時的に解糖系を中心に検討を加光た。対照 群では断頭後, 脳組織内在性エネルギー源のす久やか な減少と lactate の増加が認められた. SAM 投与群で は断頭時すでに脳内 glucose の有意な増加が認めら れ, 断頭後, 脳組織内在性エネルギ一源濃度は対照群 に比して高い值を示した. 断頭後の high energy phosphate utilization を検討したところ, 断頭10秒後まで はSAM 投与群で対照群の $77.1 \%$ に抑制されており, 断頭による脳組織内在性エネルギー源の枯渇までの時 間が SAM 投与によって延長された。 以上の結果から SAM がマウスの脳虚血に対して保護作用を有するこ とが明らかとなり, 臨床的に脳血管障害時の脳虚血に 対して有効である可能性が示唆された。

\section{文献}

1) Cantoni GL: Methylation of nicotinamide with a soluble enzyme system from rat liver. J Biol Chem 189: 203, 1951

2) Cantoni GL: S-adenosylmethionine; a new intermediate formed enzymatically from $\mathrm{L}$ methionine and adenosinetriphosphate. J Biol
Chem 204: 403, 1953

3) Fazio C, Andreoli V, Agnoli A, et al: Effetti terapeutici della S-adenosil-metionina (SAMe) nelle sindromi depressive. Minerva Med 64: 1515,1973

4) Nakanishi M, Uemura E, Hirai $H$, et al: On cerebral energy metabolism in experimental cerebral hemorrhage. Acta Neurol Scand 60(Suppl 72) : 332, 1979

5）関本 博, 中西正人, 中田 勲ら：脳血管傷害の病 態生化学的研究. 脳卒中 $3: 113,1981$.

6) Algeri S, Catto E, Curcio M, et al: Changes in rat brain noradrenaline and serotonin metabolism after administration of S-adenosylmethionine. In Zappia V, Usdin E, Salvatore F (eds): Biochemical and pharmacological roles of adenosylmethionine and central nervous system. New York, Pergamon Press, 1979, pp81

7) Andreoli VM, Agnoli A, Fazio C (eds): Transmethylations and central nervous system. New York, Springer-Verlag, 1978

8) Lowry OH, Passonneau JV, Hasselberger FX, et al: Effect of ischemia on known substrates and cofactors of the glycolytic pathway in brain. J Biol Chem 239: 18, 1964

9) Lowry OH, Passonneau JV : A flexible system of enzymatic analysis. New York, Academic Press, 1972

10) Good CA, Kramer H, Somogyi M: The determination of glycogen. J Biol Chem 100: 485, 1933

11) Yasuda $H$, Nakanishi $M$, Tsumagari $T$, et al: The mechanism of action of novel cerebral protective drug against anoxia. I. Effect on energy demand. Arch Intern Pharmacodyn 242 : 77, 1979

12) Levy DE, Duffy TE: Effect of ischemia on energy metabolism in the gerbil cerebral cor. tex. J Neurochem $24: 1287,1975$

13) Mrsulja BB, Lust WD, Mrsulja BJ, et al : Postischemic changes in certain metabolites following prolonged ischemia in the gerbil cortex. J Neurochem $26: 1099,1976$

14) Swaab DF, Boer $K$ : The presence of biological labil compounds during ischemia and their relationship to the EEG in rat cerebral 
cortex and hypothalamus. J Neurochem 19 : 2843, 1972

15) Ponten U, Ratcheson RA, Salford LG, et al : Optimal freezing conditions for cerebral metabolites in rats. J Neurochem 21 : 1127, 1973

16) Zappia V, Carteni-Farina M, Galletti P: Adenosylmethionine and polyamine biosynthesis in human prostate. In Salvatore F, Borek E, Zappia V, et al (eds): The biochemistry of adenosyl-methionine. New York, Columbia University Press, 1977, pp473

17) Strittmatter WJ, Hirata F, Axelrod J: Increased $\mathrm{Ca}^{2+}$-ATPase activity associated with methylation of phospholipids in human erythrocytes. Biochem Biophys Res Comm 88: 147, 1979

18) Hirata F, Axelrod J : Enzymatic methylation of phosphatidylethanolamine increases erythrocyte membrane fluidity. Nature $275: 219,1978$

19）関本 博, 松谷芳英, 片山 理ら：脳血管障害性期
の薬物療法に関する研究-リン脂質の血管内皮保 護作用の超微形態から一。臨床薬理 $14: 235$, 1983

20) Brunner EA, Passonneau JV, Molstad C: The effect of volatile anaesthetics on levels of metabolites and on metabolic rate in brain. J Neurochem 18: 2301, 1971

21) Nahorski SR, Rogers KJ: In vivo effects of amphetamine on metabolites and metabolic rate in brain. J Neurochem 21:679, 1973

22) Duffy TE, Kohle SJ, Vannucci RC: Carbohydrate and energy metabolism in perinatal rat brain : Relation to survival in anoxia. J Neurochem 24:271, 1975

23) Holowach-Thurston J, Hauhart RE, Jones EM : Anoxia in mice: Reduced glucose in brain with normal or elevated glucose in plasma and increased survival after glucose treatment. Pediat Res 8: 238, 1974

\title{
Abstract \\ The effect of S-adenosyl-L-methionine on ischemic changes in cerebral energy metabolism
}

\author{
Hiroshi Sekimoto, M.D., Masato Nakanishi, M.D., Yoshihide Matsutani, M.D., \\ Osafumi Shimada, M.D. and Toshimi Nakano, M.D. \\ Department of Gerontology, Kanazawa Medical University
}

The effect of S-adenosyl-L-methionine (SAM) on ischemic changes in cerebral energy metabolism was studied. Male dd-mice weighing $25-28 \mathrm{~g}$ were used. The animals were injected with $100 \mathrm{mg} / \mathrm{kg}$ of SAM intravenously. After $30 \mathrm{~min}$, they were decapitated and at interval of 10 or $30 \mathrm{sec}$ the heads were frozen in liquid nitrogen. The cerebral concentrations of phosphocreatine, ATP, glucose, glycogen and lactate were determined with the enzymatic fluorometric methods described by Lowry et al. from the changes in the concentrations of phosphocreatine, ATP, glucose and glycogen, the rate of cerebral high energy phosphate utilization was calculated. In control, decapitation produced immediate decrease in the levels of phosphocreatine, ATP, glucose and glycogen and increase in lactate level. In SAM-treated mice, the cerebral glucose level was significantly higher than in control at the time of decapitation, while there was no change in the other metabolites. After decapitation the cerebral levels of phosphocreatine, ATP, glucose and glycogen were higher than in control. The rate of cerebral high energy phosphate utillization during $10 \mathrm{sec}$ after decapitation in SAM-treated mice fell to $77.1 \%$ of that in control. It is suggested that SAM improved the cerebral energy metabolism on ischemia and that SAM may be of clinical use in the treatment of stroke.

(Jpn. J. Stroke 6: 405-410, 1984) 